\title{
Chapter 19 \\ France
}

\author{
Julie Rochut and Jim Ogg
}

\begin{abstract}
France is characterised by a low labour force participation rate after of the age of 60. Recent and current reforms aim to increase the working life: raising the legal retirement age and increasing the duration of insurance contributions to obtain a full pension. Women have more career breaks, higher rates of part-time work and therefore lower pensions than men. Workers in hazardous jobs or with long careers can under certain conditions retire earlier than the legal age of 62 years. The gender inequalities observed in early years of employment are exacerbated in the latter part of the working life.
\end{abstract}

Keywords Gender · French pension reforms $\cdot$ Hazardous work

\section{Introduction}

France has a specific employment context with a relatively high unemployment rate and several measures that, until recently, have tended to make older workers leave the labour market prematurely. From 2003 governments have introduced reforms that encourage older workers to remain in the labour market.

\section{Gender and Employment in France}

The rise in the proportion of women in the labour market during the latter half of the twentieth century that has been a feature of many European countries is also present in France. Marchand and Thélot (1991) have identified two main phases in the development of women's work. The first phase, extending from the 1900s to the 1960s, was characterised by a decline in women's employment, after a full century of growth throughout the 19th century, while the second, beginning around 1965, saw a dramatic reversal of this trend. The turnaround in the 1960 s can be

J. Rochut $(\bowtie) \cdot$ J. Ogg

Ageing Research Unit, National Pension Fund (Cnav), Paris, France

e-mail: julie.rochut@cnav.fr 
attributed mainly to the massive entry of married women-with children-into the labour market, combined with a major shift in values, where the model of the working mother supplanted that of the stay-at-home or full-time mother.

Compared to other European countries, France displays an intermediary level of participation with $61 \%$ of women at work in 2015 , an increase of $8.5 \%$ since 1995 (Geraci and Lavigne 2017). However, in the 2000s, 70\% of French women experienced at least one career break since their first job compared with only $50 \%$ of men. Other than redundancy, the main reason for women's career breaks is for child-rearing.

The employment rate gap between men and women in the age group 55-64 years has been around five per cent since 2007 (compared to approximately $10 \%$ for women aged 25-54 years), and the unemployment rate is very similar between men and women (around 6\%). The employment rate of older workers has increased in recent years for both women and men: the proportion of women aged 50-64 in paid employment increased between 2007 and 2017 from 49.9 to $59.1 \%$ and that of men from 56.9 to $64.0 \%$. While women aged 50-54 or 55-59 are less likely to work than men of the same age, in 2017 women aged 60-64 are slightly more likely (29.8\%) to be in paid work compared to men $(28.6 \%$ ) (Beck and Vidalenc 2018) indicating the need for women to work longer in order to increase the level of their pension.

Although the proportion of women in part-time jobs has been stable in France at around 30\% between 1995-2015 (Geraci and Lavigne 2017) a larger proportion of women are in part-time jobs than men and this exposes women to greater risks of poverty in retirement.

Women also experience discrimination and inequality in terms of employment, career opportunities and salaries. The salary gap between men and women is about $15 \%$ (Eurostat 2016). The gender inequalities observed in early years of employment are exacerbated in the latter part of the working life. These differences are mainly due to the rise in female labour force participation experienced by baby boomers, which clearly differ from women of previous cohorts, many of whom permanently left the labour force after the birth of their first child. In 2012, one in four retired women had less than 25 years of accumulated working life (Hourriez 2015). A short working life is in turn reflected in significantly lower pension levels among women who are currently retired. In 2016, the mean gross State pension for men was $€ 1,739$ per month compared to $€ 1,065$ for women (Drees 2018). Pension levels for women are lower than for men, even when women have had a full working life, although the pension income gap has narrowed over recent years (see Chap. 1). Because women continue to experience gaps in their working life histories they increasingly work longer to maximise their pension (Bonnet et al. 2006).

A further gender difference in income levels in the context of extending working life concerns divorced women. As in other European countries, France's divorce rates have increased (Bellamy 2017) and the consequences of this trend have significantly lowered levels of income among divorced older women, mirroring those of widows, which may compel divorced women to remain in work longer.

Since 2000, the participation of older workers in the labour market has increased rapidly due to the decrease of early retirement measures, demographic changes and 
pension reforms - the employment rate of older workers (aged 55-64) has increased by $15 \%$ since 2003 . However, France has one of the lowest rates of employment in Europe for men aged 60-64: 27.7\% in 2016 (Eurostat 2017). Rates are also relatively low for women $(28.4 \%)$ compared to other European women in the same age group (approximately 48\%).

This increase for the 55-64 year old group has also gone hand in hand with a strong development of part-time work and a worsening state of health of this age group in the labour market. In 2016, workers over the age of 55 more often have part-time jobs than younger workers. A small proportion of these older part-time workers have more than one job. For older workers, part-time work is frequently due to personal, domestic and health reasons. Manual workers are 5.6 times more likely to report working part-time for health reasons than executives. Among older workers, gender and occupational status differences in part-time work are identical to those observed for part-time workers in mid-life careers. However, differences appear between the age groups 55-59 and 60-64, with part-time work being more widespread and with shorter hours among the latter group (Letroublon 2017).

This low participation is also a matter of family organisation. One-fifth of men and women aged 51-60 years care for a sick, elderly or disabled family member. Among these caregivers, 58.6\% are women (Prouet and Rousselon 2018) and the average time spent caring by women is significantly higher than men. Lifecourse lag (end of studies, age at maternity, end of working life, later mortality) increases the likelihood of multiple family obligations for older workers. Extended working life reduces the availability of informal carers but it can also increase incentives to continue earning through paid work to finance family obligations. The proportion of individuals who retire totally or partially because of family reasons is increasing.

\section{Pension System and Extended Working Life Pension Policies in France}

There are three pension tiers in France. A main public pension system provides income amounting to roughly 14 per cent of GDP (COR 2015). This main scheme for wage earners of the private sector is the most important public pension scheme, covering more than two thirds of the working population. Together with its complementary point-based public second pillar which is based on contributions deducted from wages, it provides the main source of income during retirement, with a median replacement rate of last earnings of $75 \%$ for continuous careers. For people born before 1948, 160 quarters validated were required. A quarter is validated on the basis of yearly earnings: an equivalent of $150 \mathrm{~h}$ paid for workers earning at least the minimum wages validates one quarter, regardless of the actual work duration. This validation gives entitlement for a future pension. Since the reforms, the number of quarters increases by one for every two generations to reach 172 quarters for the generation born in 1973 and thereafter. A supplementary voluntary private pension 
is the third tier, but it represents only two per cent of the total of retirement pensions and benefits received. In 2014, the average standard of living of retirees was slightly higher than in the overall population, the ratio between the two being $106.1 \%$ (103.3\% for women and $109.3 \%$ for men) (COR 2017). A systemic reform of the French pension system was announced by the Government at the end of 2019, based on the Swedish Pay-As-You-Go notional accounts system. However, the proposed reforms have been met with protest as the system disadvantages certain professions and rises significantly the minimum pension age (without a degressive penalty) from 62 to 64 years.

Several measures that aim to extend the working life have been recently implemented:

- Postponing the legal retirement age. The aim of these reforms has been to push back the age at which a worker is eligible for a full rate pension. Since 2010, the legal retirement age has been raised progressively by four months for each generation, for the birth cohorts 1951-1956, to reach 62 years for men and women. However, if workers do not have a full career, penalty points are applied that reduce the level of the pension. The age at which no penalty points are applied has been raised from 65 to 67 years. Since 2012, for workers with an unusually long career (those who started working before age 20 with a full career or more than 40 years worked) it is possible to retire at age 60 . Approximately 150,000 people retire each year at age 60 after a long career (75\% are men). Besides the positive effect on employment rates, increasing the statutory retirement age can also have an impact on other public insurance schemes, such as unemployment insurance, disability insurance or sick pay insurance. Older individuals already out of employment may not react to the incentives to return to work, and simply stay longer on the bridge between employment and retirement. Workers who for a long time expected to retire at age 60 may exit the labour market and use alternative schemes to fill their income gap until retirement. Recent evidence suggests that the increase in the legal retirement age from 60 to 62 has also increased the number of people resorting to unemployment or disability benefits in the years preceding retirement. This means that the objective of extending working life has only been partially achieved by increasing the retirement age: only $40 \%$ of people who would have normally retired at age 60 continue to work until age 61 , whereas one third remain unemployed, one-sixth receive disability or invalidity benefits, and one-sixth are out of the labour market completely (Rabaté and Rochut 2019).

- Surcote: pension premium. For workers retiring after the current legal age of 62 and having more than the required number of contributions for a full pension, a premium can be set under certain conditions to increase the pension. Each quarter contributed beyond the statutory retirement age increases the retirement pension by $1.25 \%$. Approximately $15 \%$ of pensions for employees in the private sector are paid each year with a premium (Berteau-Rappin 2018). Professional status is significantly associated with the choice to retire with a premium: being a manager and having a high income increases the probability of deferring retirement with a premium (Aouici and Rochut 2017). Moreover, workers who anticipate economic 
difficulties are also more likely to retire later with a premium. For instance, home buyers are more likely to extend working life, probably in order to pay off their mortgage.

- Décote: pension relief. If a worker decides to retire after the legal minimum age (62) and before the age of 67 but without a full number of contributions, a discount factor is applied. It is a discount coefficient applied for each missing quarter, inducing a decrease compared to the full rate. The discount of $1.25 \%$ (for a worker born before 1944) for each quarter missing (5\% per year) was gradually reduced to $0.625 \%$ (for a worker born after 1952). Only ten per cent of pensions paid each year are with a discount factor. The proportion is slightly higher for women than for men (11\% vs. $8 \%$ respectively).

- Mandatory retirement. The mandatory retirement age is the age at which an employer can choose to separate from an employee-without dismissal-even if the employee does not wish to leave. This age was set at 65 until 1 January 2009; it is now 70 years. Rabaté (2017) finds that mandatory retirement does affect retirement patterns: exit rates from employment are estimated to be six per cent higher when mandatory retirement is possible.

- Préretraite - preretirement or early retirement. Two types of preretirement exist. Private ones are implemented by firms. Although French companies are taxed for implementing early retirement, many continue to use early retirement measures. Companies may opt for the preretirement of employees when they restructure management, and employees take preretirement often in the context of planned job protection measures. However, the use of early retirement as a tool to manage age pyramids which was predominant in the years 1970-1980, has decreased. Since the mid-1990s, early retirement in the public pension system has experienced tightening conditions of access and public funding. A preretirement measure allows people to keep their level of wage before retirement. In 2009 only 50,650 employees from the private sector received a state preretirement pension compared to more than 200,000 employees in 1999 (Merlier 2010).

- Combination of employment and retirement-Gradual retirement: 'retraite progressive' and 'cumul emploi retraite'. After the abolition of early retirement as a government policy initiative, public authorities have encouraged extending working life through two measures. The retraite progressive measure eases the transition to retirement by allowing an individual to combine part-time work with drawing a proportion of their pension and enabling retirement contributions to be paid to increase further the value of the full pension. This dates from 1988 but is still very little used-only 8,000 people in 2016 and mostly women (70\%). The reasons for this low take-up are complex, but they include spin-off effects for second pillar pensions and a strong normative attachment to retirement on achieving eligibility. A combination of retirement and employment is more widespread, and more than 400,000 persons work and receive a retirement pension among a total of 14 million retirees, a proportion of less than three per cent. 


\section{Unemployment Policies}

'Convention d'assurance chômage'-Unemployment benefit conditions. The current unemployment insurance agreement defines a single benefit profile where the length of compensation is equal to the covered work experience. Since 1 October 2017, the maximum duration has been fixed to two years (730 days) until age 53, two and a half years (913 days) between age 53 to 54, and three years (1,095 days) from age 55 . The impact of a longer compensation for older workers is controversial since longer unemployment benefit duration can be seen either as a disincentive to re-enter paid employment or as a measure allowing more time to help unemployed workers find a job that fits their profile. The pension reforms announced in 2019 reform do not change unemployment benefit conditions for senior workers - the affiliation duration does not change and senior workers aged 57 years or more are not impacted by the decrease of the benefit.

\section{Health Policies}

Compte pénibilité-Hazardous working conditions account. Increased life expectancy and longer careers operate unevenly across occupations: many employees approach retirement age in deteriorated physical conditions. A personal account aimed at preventing the impact of harsh working conditions was introduced in 2016. Since October 2017, the definition of annual thresholds associated with each of the six occupational risk factors were set out in the Labour Code, defined as factors of strain (hyperbaric activities, high temperature, noisy environment, night work, work in alternating teams, repetitive tasks). Employers must identify employees for whom the threshold is exceeded for one or more factors. Hence, the account allows employees exposed beyond the thresholds to gain points, which can be used to fund either training opportunities to access less arduous jobs, or a reduction in working hours with wage loss compensation or retiring earlier with a maximum of two years earlier than the legal age of retirement.

\section{Debate on Extending Working Life}

Measures to extending working life remain unpopular among the general population. Many workers feel that promises made earlier in their career that set the retirement age to 60 have been broken. There is also a widespread view among the general population that older workers should give up their job for the benefit of younger workers who encounter difficulties in finding permanent jobs. Among the civic sector and trade unions, the debate on extending working life is focused on the need to protect long career workers and those with hazardous occupations. The precarious nature of jobs 
(short-term temporary contracts), closures and relocation of industries in localised areas where few alternative jobs are available are often evoked as major obstacles to extended working life.

According to Guillemard (2013), the organisation and structure of retirement systems play an important role in defining of 'old age' as a period of inactivity that follows a working career. She has analysed the phenomenon of early withdrawal from the labour market which was a strong feature of the French retirement system during the 1980s and 1990s. Following the oil crisis of 1973, French social policy converged by focusing on early withdrawal by older workers from the labour force. Far from providing workers with a secure retirement, policies directed towards early labour market exit were driven by economic uncertainties and rapidly changing organisational structures of employers.

Currently a reform of the retirement system is under consideration. The aim of the reform is to change the current system into a notional account system. However, the debate on pension age is still lively. Recently, the Minister of health gave a controversial interview in which she claimed that the minimum pension age should be 64 (instead of 62). The trade unions have reacted strongly claiming that it is a spurious debate because high unemployment persists and under these conditions the risk is to increase the precarity of older workers. The debate on extending working life is not finished.

\section{Gender and Health Implications of Extending Working Life?}

Firmly grounded in a lifecourse approach, research at the unit 'Ageing and Work' at the Centre for Employment Studies (Volkoff 2012), has studied gender differences relating to ageing, work and health. Attention is given not only to how ageing men and women adapt in relation to work but also how the workplace and employers' attitudes towards workers develop in the context of an ageing workforce. Several French epidemiological studies have demonstrated the effect of workplace conditions and organisational transformations for the ageing worker. David and colleagues (2001) observe that industries and business mostly regard the ageing of their workforce negatively, both in terms of financial cost and the capacity of workers to perform their jobs.

The ESTEV (enquête santé travail et vieillissement) panel survey clearly demonstrated that for both men and women, older manual workers had a higher prevalence of musculoskeletal disorders and high blood pressure than non-manual workers. Furthermore, even controlling by age and type of occupation, for both genders, health problems depend on the work's physical requirements or constraints (carrying heavy loads, efforts on tools, constraining postures, etc.), on the work schedule requirements (alternating, atypical schedules, etc.) and on other organisational choices such as the decisional latitude and high psychocognitive demand (David et al. 2001).

According to Chappert and Théry (2016), little research exists on certain aspects of working conditions and especially how they are experienced by women. These 
include gender differences in the exposure to hazardous risks, psychosocial risks, older workers, working hours and professions that are predominately mono-gender. Bouffartigues and colleagues (2010) have found that a higher proportion of women report a positive effect of work on their health than men. At the same time, women are more likely to experience higher levels of psychosocial problems.

Research has also been undertaken on the wider consequences of extending working life for social and voluntary participation, grandparenting and caring for older parents (Jolivet and Zahiri 2010). These studies focus on the potential consequences for intergenerational solidarity arising from increasing the length of the working life, both in the public and private domains. Concerning women, combining work and caring has increasingly attracted attention, given the fact that older women are key carers for both their ageing parents and grandchildren (Bonvalet et al. 2015; Le Bihan and Martin 2010).

Research has also been undertaken on life expectancy without disability and the implications for extending working life. As in other European countries, inequalities in life expectancy without disability exist between men and women but they are compounded by social factors among which work and career histories are prominent. Research has shown that not only do higher socio-professional groups have a greater life expectancy than manual workers, but also that manual workers have a greater number of average years spent with a disability (Cambois and Robine 2013). This phenomenon is known as the 'double penalty of manual workers'.

\section{Conclusion}

Extended working life in France is mostly being implemented by institutional measures such as pension eligibility rules. These are increasing the average age at which workers retire, but there is little evidence for the desire to extend working life. Many women are adversely affected by extended working life measures, in so far as they are obliged to work longer to secure an adequate income. Continued high rates of unemployment create structural barriers to government aims of reducing state expenditure on retirement pensions. Measures such as the harsh working conditions account and early retirement for long careers protect workers from the adverse effects of extended working life, although these measures have been politically difficult to introduce (often in the face of criticism by employers) and their future remain uncertain. Part-time jobs at the end of the career, could become more widespread and this needs to be addressed by policy makers.

\section{References}

Aouici, S., \& Rochut, J. (2017). Which factors influence premium deferred retirement decision? Paper presented at 13th Conference of the European Sociological Association, Athens, 
Greece. https://www.statistiques-recherches.cnav.fr/colloques-et-seminaires.html. Accessed 4 March 2019.

Beck, S., \& Vidalenc, L. (2018). L'emploi des seniors en hausse entre 2007 et 2017: plus de temps partiel et d'emplois à durée limitée [Increase of senior employment between 2007 and 2017: more part time]. Insee Focus $\mathrm{N}^{\circ}$ 119. https://www.insee.fr/fr/statistiques/3582878. Accessed 4 March 2019.

Bellamy, V. (2017). 236300 mariages célébrés en France en 2015, dont 33800 mariages mixtes [236 000 weddings in France in 2015, 33800 mixed-race marriage]. Insee Première, $n^{\circ} 1638$. https://www.insee.fr/fr/statistiques/2656612. Accessed 1 March 2019.

Berteau-Rappin, C. (2018). Prendre sa retraite: incidence des dispositifs de prolongation d'activité sur les parcours individuels [Retirement: impact of extending working life measures] Cahier de la Cnav, 11, 65-91

Bonnet, C., Buffeteau, S., \& Godefroy, P. (2006). Les effets des réformes des retraites sur les inégalités de genre en France [Impact of retirement reforms on gender inequalities in France]. Population, 61(1), 45-75.

Bouffartigues, P., Pendariès, J. R., \& Bouteiller, J. (2010). La perception des liens travail santé [Perception of health and labour relationship]. Revue française de Sociologie, 51(2), 247-280.

Bonvalet C., Clément C., Ogg J. (2015). Renewing the Family: A History of the Baby Boomers. Paris: INED Population Studies, Vol. 4.

Cambois E., \& Robine J-M. (2013). Les espérances de vie en bonne santé des Européens [Europeans healthy life expectancies]. Population \& Sociétés, 499, 1-4. https://www.ined.fr/fr/publications/ editions/population-et-societes/pdf. Accessed 1 March 2019.

Chappert, F., \& Théry, L. (2016). Égalité entre les femmes et les hommes et santé au travail. Comment le genre transforme-t-il l'intervention sur les conditions de travail? [Equality between men and women and occupational health]. Perspectives interdisciplinaires sur le travail et la santé. https://doi.org/10.4000/pistes.4882.

COR - Conseil d'orientation des retraites (2015). Évolutions et perspectives des retraites en France. Rapport annuel du COR Juin 2015. Paris: La Documentation française.

COR-Conseil d'orientation des retraites (2017). Évolutions et perspectives des retraites en France. Rapport annuel du COR Juin 2017. Paris: La Documentation française.

David, H., Volkoff, S., Cloutier, E., Derriennic, F. (2001). Vieillissement, organisation du travail et santé [Ageing, work organisation and health]. Perspectives interdisciplinaires sur le travail et la santé. https://doi.org/10.4000/pistes.3745, https://journals.openedition.org/pistes/3745? gathStatIcon=true\&lang=fr. Accessed 1 March 2019.

Drees_Direction de la recherche, des études, de l'évaluation et des statistiques (2018). Les retraités et les retraites. Paris: Drees.

Eurostat (2016). Gender pay gap database. https://ec.europa.eu/eurostat/statistics-explained/index. php/Gender_pay_gap_statistics. Accessed 1 March 2019.

Eurostat. (2017). Employment and unemployment (Labour force survey) database. https://ec. europa.eu/eurostat/web/lfs/data/database. Accessed 1 March 2019.

Geraci, M., \& Lavigne, A. (2017). Les écarts de pension entre les femmes et les hommes: un état des lieux en Europe [Gender pension gap: assessment in Europe]. Insee Référence Femmes, hommes l'égalité en question. https://www.insee.fr/fr/statistiques/2586548. Accessed 1 March 2019.

Guillemard, A. M. (2013). Prolonging working life in an aging world: A cross-national perspective on labor market and welfare policies toward active aging. In J. Field, R. J. Burke, \& C. L. Cooper (Eds.), The SAGE handbook of aging, work and society (pp. 60-73). London: SAGE.

Hourriez, J. M. (2015). Les revenus des retraités [Retirees' income]. Retraite et société, 1, 139-150. Jolivet, A., \& Zahiri, E. (2010). Travailler plus longtemps (Working longer). Paris: La documentation française.

Le Bihan-Youinou, B., \& Martin, C. (2010). Prise en charge d'un parent âgé dépendant et vie professionnelles [Caring old relatives and working life]. In A. Jolivet, E. Zahiri, \& E. Travailler (Eds.), plus longtemps (pp. 973-974). Paris: La documentation française. 
Letroublon, C. (2017). Les seniors au travail: la durée du travail est-elle plus faible à l'approche de la retraite ? (Seniors workers: which working hours?) Dares analyse $\mathrm{N}^{\mathrm{o}} 050$. https://dares.travailemploi.gouv.fr/IMG/pdf/2017-050.pdf. Accessed 3 March 2019.

Marchand, O., \& Thélot, C. (1991). Deux siècles de travail en France [Two centuries of work in France]. Paris: Etudes Insee.

Merlier, R. (2010). Les préretraites publiques en 2009: dix fois moins d'entrées qu'en 1999 [Public pre-retirement in 2009: ten times less entries than in 1999]. Dares analyse, $\mathrm{N}^{\mathrm{o}} 062$. https://dares. travail-emploi.gouv.fr/IMG/pdf/2010-062.pdf. Accessed 3 March 2019.

Prouet E., \& Rousselon J. (2018). Les seniors, l'emploi et la retraite [Seniors, employment and retirement]. Rapport France strategie. https://www.strategie.gouv.fr/publications/seniorslemploi-retraite. Accessed 3 March 2019.

Rabaté, S. (2017). Can I Stay or Should I Go? Mandatory Retirement and Labor Force Participation of Older Workers. PSE Working Papers n²017-19. https://halshs.archives-ouvertes.fr/halshs01521150. Accessed 3 March 2019.

Rabaté, S., \& Rochut, J. (2019). Employment and substitution effects of raising the statutory retirement age in France. Journal of Pension Economics and Finance. https://doi.org/10.1017/ S1474747218000392.

Volkoff S. (2012). Les "séniors" pourront-ils travailler plus longtemps? [Will seniors able to work longer?]. In M.-J. Thiel (Ed.), L'automne de la vie. Enjeux éthiques du vieillissement (pp. 109122). Strasbourg: Presses Universitaires de Strasbourg.

Open Access This chapter is licensed under the terms of the Creative Commons Attribution 4.0 International License (http://creativecommons.org/licenses/by/4.0/), which permits use, sharing, adaptation, distribution and reproduction in any medium or format, as long as you give appropriate credit to the original author(s) and the source, provide a link to the Creative Commons license and indicate if changes were made.

The images or other third party material in this chapter are included in the chapter's Creative Commons license, unless indicated otherwise in a credit line to the material. If material is not included in the chapter's Creative Commons license and your intended use is not permitted by statutory regulation or exceeds the permitted use, you will need to obtain permission directly from the copyright holder.

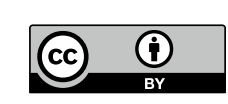

